\title{
Dexketoprofen trometamol loaded solid lipid nanoparticles (SLNs): Formulation, in vitro and in vivo evaluation
}

\author{
A. Alper ÖZTÜRK ${ }^{*}$ (D), Evrim YENILMEZ 1 (D), Rana ARSLAN 2 (D), Behiye ŞENEL ${ }^{3}$ (D), \\ Yasemin YAZAN 1 (D)
}

1 Department of Pharmaceutical Technology, Faculty of Pharmacy, Anadolu University, Eskişehir, Turkey.

2 Department of Pharmacology, Faculty of Pharmacy, Anadolu University, Eskişehir, Turkey.

3 Department of Pharmaceutical Biotechnology, Faculty of Pharmacy, Anadolu University, Eskişehir, Turkey.

* Corresponding Author. E-mail: aaozturk@anadolu.edu.tr (A.A.Ö.); Tel. +90-222-335 05 80/37 31.

Received: 06 September 2019 / Revised: 13 December 2019/ Accepted: 23 December 2019

ABSTRACT: Development, in vitro and in vivo evaluation of dexketoprofen trometamol (DT)-loaded nanosized drug delivery system was aimed in this study. DT-loaded solid lipid nanoparticles (SLNs) were prepared using probe sonication. DT release from SLNs prepared and their kinetics were investigated. Structures of SLNs were elucidated by particle size and zeta potential measurements, shape and surface imaging, thermal analysis, X-ray diffraction, FT-IR and ${ }^{1} \mathrm{H}-\mathrm{NMR}$ determinations. DT-loaded particles demonstrated characteristic plaque shapes while in vitro release studies showed extended release of DT. Korsmeyer-Peppas kinetic model was found to fit the best using DDSolver software program. Stability, cytotoxicity and in vivo animal experiments were further performed on DT-loaded SLN showing also prolonged analgesic activity in mice. Depending on the in vitro and in vivo test results, formulation developed in this study seems to prolong DT release and is promising for extending analgesic activity.

KEYWORDS: Dexketoprofen trometamol; solid lipid nanoparticle (SLN); probe sonication.

\section{INTRODUCTION}

Pain is defined as unpleasant or emotional experience associated with actual or potential tissue damage. Physical and psychological factors combine together to form the pain experience and thus being variable and multi-dimensional. Although pain has a useful function in preventing tissue damage, there is no similar benefit in the postoperative period or as it becomes chronic. Acute pain which is a sign of tissue damage is an evidence of a functional nervous system. Autonomic hyperactivity reactions such as hypertension, tachycardia, excessive sweating and vasoconstriction are observed with acute pain. Patient population with chronic pain is very high throughout the world. Annual expenditure on pain treatment is higher than many other diseases $[1,2]$.

Non-steroidal anti-inflammatory drugs (NSAIDs) and narcotic analgesics are the most commonly used drugs in pain treatment. NSAIDs are simply called 'anti-inflammatory analgesics'. The analgesic effect of a NSAID is lower than narcotic analgesics but it is the most commonly prescribed analgesic active substance group because of its non-dependence and non-narcotic state. The use of NSAIDs for long-term inflammationrelated treatment is one of the most important benefits of this group as narcotic analgesics do not have antiinflammatory activity. Although NSAIDs are a popular group in the treatment of pain, side effects can be observed in the gastrointestinal system (GIS) ranging from dyspepsia to stomach uptake, which can lead to death. NSAIDs are sold in many countries as over-the-counter (OTC) drugs [3, 4]. Anti-inflammatory effect of NSAIDs is by directly inhibiting prostaglandin synthesis though inhibiting cyclooxygenase (COX) enzyme and resulting consequently in inhibition of inflammation [5]. A NSAID, aryl propionic acid is a racemic mixture of two enantiomers. The $S(+)$ enantiomer shows cyclooxygenase (COX) inhibition [6] where dexketoprofen trometamol (DT) (ketoprofen $S(+)$ tromethamine salt) is an example. While the analgesic and anti-inflammatory effects of $S(+)$ enantiomer in racemic ketoprofen strongly inhibits prostaglandin synthesis in vitro, $\mathrm{R}(-)$ enantiomer is devoid of those activities. DT which is a D-converting enantiomer of non-steroidal

How to cite this article: Öztürk AA, Yenilmez E, Arslan R, Şenel B, Yazan Y. Dexketoprofen trometamol loaded solid lipid nanoparticles (SLNs): Formulation, in vitro and in vivo evaluation. J Res Pharm. 2020; 24(1): 82-99. 
ketoprofen was used for more than 20 years as an analgesic all over the world with its analgesic effect lasting 4-6 hours [7, 8]. DT, produced as the water-soluble salt of dexketoprofen, is used in the European Union countries for the symptomatic treatment of all mild to moderate pain such as musculoskeletal pain, dysmenorrhea and dental pain as immediate release standard tablets at doses of $12.5 \mathrm{mg}$ and $25 \mathrm{mg}$. In a study comparing DT and ketoprofen in healthy volunteers, DT demonstrated rapid plasma absorption with high plasma concentration and was a good choice for acute use [9]. Chemical structure of DT is presented in Figure 1.

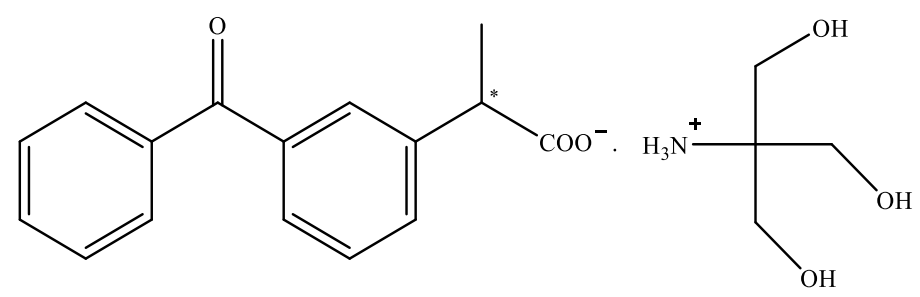

Figure 1. Chemical structure of DT.

Solid lipid nanoparticle (SLN), one of the nanotechnology-based drug delivery systems, has recently gained attention for providing controlled release of drugs in the body. SLNs are biodegradable/biocompatible colloidal drug delivery systems with particle size of 50-1000 nm and which are stabilized by surfactant and solid at room/body temperature. SLN was developed as an alternative system to liposomes and polymeric nanoparticles [10]. SLN has several advantages over other colloidal carrier systems including increase in stability, extended release and targeting of active agents. Both lipophilic and hydrophilic active agents can be loaded into SLNs [11]. Besides its advantages SLN system has some disadvantages limiting its use among which are low loading capacity, leakage of active agent at storage conditions and high content of water in dispersion (70-99.9\%) [12].

The most frequently used methods in SLN production are high pressure homogenization, microemulsion, cold/hot homogenization, solvent emulsification, diffusion, high speed mixing and ultrasonication methods [13]. High-speed mixing and ultrasonication methods can be used either together or separately representing common and easy application. The problem of micrometer sized particles obtained with mixing at high speed can be overcome by ultrasonication [11]. Ultrasonic devices are basically divided into three classes: ultrasonic bath, ultrasonic probe and sono-reactor devices. Basic difference between an ultrasonic probe and an ultrasonic bath is that ultrasonic probe is in direct contact with the solution or mixture [14]. All types of sonication are available in a range of intensity and output power settings, sometimes adapted with a different type of sonotrode for specific processes or requirements and are suitable for liquid volumes ranging from 2 to $250 \mathrm{~mL}$. Although probe ultrasonication is known to perform better than bath sonication because of high localized intensity. Similarly, an ultrasonic probe fitted with a vial tweeter is advantageous over the direct probe due to the above-mentioned contamination risks as well as the operation friendliness of the equipment. Several vials are sonicated at the same time and at the same intensity. This not only saves time but ensures that all the samples are treated equally, which makes the results among samples more reliable and comparable [15].

SLN formulations generally consist of solid lipid, surfactant and water. Among the solid lipids used for SLN preparation are triglycerides, partial glycerides, fatty acids, steroids and waxes. All surfactant groups were used to stabilize lipid dispersions regardless of their amount and molecular weight [11]. Compritol ${ }^{\circledR} 888$ ATO is a solid lipid composed of a mixture of glycerol monobehenate $(12-18 \% \mathrm{w} / \mathrm{w})$, glycerol dibehenate (45$54 \% \mathrm{w} / \mathrm{w})$ and glycerol tribehenate $(28-32 \% \mathrm{w} / \mathrm{w})$. Its melting point is in the range of $69-74^{\circ} \mathrm{C}$ and its HLB value is about 2 [16]. It is physically present as a fine white powder or semi-solid pellet. Compritol ${ }^{\circledR} 888$ ATO is used as an active ingredient encapsulation, as a lubricant in tablet or capsule formulations and also as a vehicle in matrix tablets [16]. Dynasan ${ }^{\circledR}$ is a solid lipid constituting of a chemical mixture of di- and triglycerides. Melting point of Dynasan ${ }^{\circledR}$, which is physically fine white powder, is $55-58^{\circ} \mathrm{C}$. Dynasan ${ }^{\circledR} 114$ is used as a lubricant in modified or sustained release drug delivery systems and in tablet/capsule formulations [17]. Compritol ${ }^{\circledR} 888$ ATO and Dynasan ${ }^{\circledR} 114$ was preferred in this study because it has acceptable regulatory and safety profiles and can be applied as an innovative adjuvant in pharmaceutical technology [16, 17].

In this study, Compritol ${ }^{\circledR} 888$ ATO and Dynasan ${ }^{\circledR} 114$ SLNs were formulated for controlling release of DT aiming efficient treatment of pain. Probe ultrasonication method was used to prepare DT-loaded SLN formulations. In comparison to other ultrasonication methods, the same conditions can be easily achieved 
during the preparation process and repeatability ratio is higher with the probe sonication method [15]. Additionally, particle size and distribution can easily be governed by the researcher by changing the amount of power applied in the probe sonication method, which allows working at low sample volumes. Within the context of SLN studies, no DT-loaded SLN system was developed so far.

\section{RESULT AND DISCUSSION}

\subsection{Characterization}

\subsubsection{Particle size, polydispersity index and zeta potential}

Particle size, polydispersity index, zeta potential and drug loading efficiency results obtained are given in Table 1. SLN preparation parameters are the main factors affecting particle size and distribution. In probe ultrasonication method, particle size is decreased by increases in ultrasonic power and ultrasonic power application time [18]. Small particle size was obtained in this study by probe ultrasonication method. Polydispersity index (PDI) is the parameter used to define particle size distribution. PDI value can be in the range from 0.01 to about $0.5-0.7$ for single phase systems. Values higher than 0.7 are indicative of a very large particle size distribution [19]. PDI values of SLN formulations prepared in this study were found to be in the range of $0.213-0.345$ which showed uniform distribution. Zeta potential value is very important in assessing the physical stability of colloidal systems and their interaction with biological membranes. Colloidal particles are loaded positively or negatively by adsorbing ions from the dispersion medium where zeta potential value indicates net effective load on the particle. High zeta potential value $(+/-30 \mathrm{mV})$ represents stable colloidal dispersion. Generally, particle clustering is less likely to occur with high zeta potential value due to electrical repulsion between particles [20, 21]. In this study, zeta potential values of $-8.72 \pm 1.51 \mathrm{mV}$ (mean \pm SE), $11.60 \pm 0.15 \mathrm{mV}$ (mean \pm SE), $-11.60 \pm 0.15 \mathrm{mV}$ (mean \pm SE) and $-13.55 \pm 0.70 \mathrm{mV}$ (mean \pm SE) were determined for COMP-E, COMP-DT, DYN-E and DYN-DT, respectively. It can be predicted that the formulations prepared are unstable in long term according to the literature.

Table 1. Particle size, polydispersity index, zeta potential and drug loading efficiency of SLN formulations.

\begin{tabular}{ccccc}
\hline Code & PS $(\mathbf{n m}) \pm$ SE & PDI \pm SE & ZP \pm SE & DL\% \pm SE \\
\hline COMP-E & $92.361 \pm 0.672$ & $0.226 \pm 0.032$ & $-8.72 \pm 1.51$ & - \\
COMP-DT & $100.410 \pm 1.820$ & $0.345 \pm 0.050$ & $-10.80 \pm 0.05$ & $8.802 \pm 1.747$ \\
DYN-E & $136.030 \pm 1.525$ & $0.255 \pm 0.003$ & $-11.60 \pm 0.15$ & - \\
DYN-DT & $137.605 \pm 1.250$ & $0.213 \pm 0.012$ & $-13.55 \pm 0.70$ & $11.612 \pm 0.204$ \\
\hline
\end{tabular}

*PS: Particle size, PDI: Polydispersity index, ZP: Zeta potential, DL\%: Drug loading, SE: Standard error

\subsubsection{Morphology}

SEM images of pure DT and SLN formulations are given in Figure 2. SLN formulations may be in the form of platelets or spheroidal distant because of the tendency of some lipid particles to crystallize [11]. In this study, characteristic plate shapes were obtained. No specific DT crystal structure observed indicated successful loading of DT into solid lipids.

\subsubsection{Differential scanning calorimetry (DSC)}

DSC profiles of formulations are given in Figure 3. No new peak belonging to lipid appeared in the DSC profiles of SLN formulations. This showed that Compritol ${ }^{\circledR} 888$ ATO and Dynasan ${ }^{\circledR} 114$ do not interfere with DT or there is no incompatibility. Melting points of the SLN formulations prepared in this study were slightly lower than that of pure solid lipid which may be attributed to small particle size/increased surface area obtained by the probe ultrasonication method or to the presence of low surfactant in the medium or this depression was attributed to defects in crystalline lattice. Ingredients, like surfactants, distributed in the melted lipid phase during the production process of SLNs distort crystals resulting in a lower melting enthalpy. Depression in melting point of the SLN can also be explained by the Kelvin effect, particles in the nanometer range and their specific surface area. Reduced particle size and increased surface area lead to a decrease in the melting enthalpy compared to the heat flow though larger crystals [22, 23, 24]. 

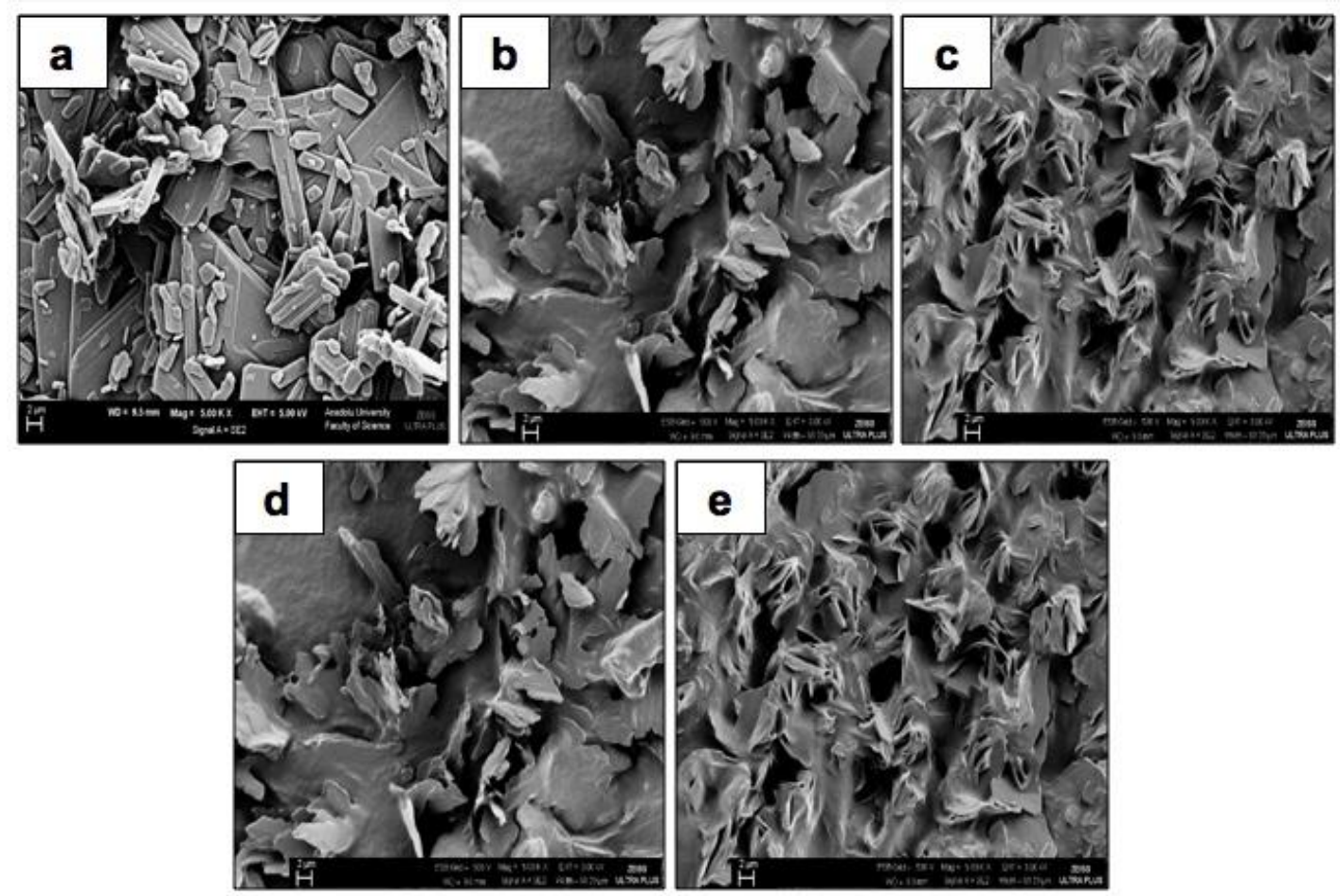

Figure 2. SEM images of pure DT and SLN formulations, a: Pure DT, b: COMP-E, c: COMP-DT, d: DYN-E, e: DYN-DT.
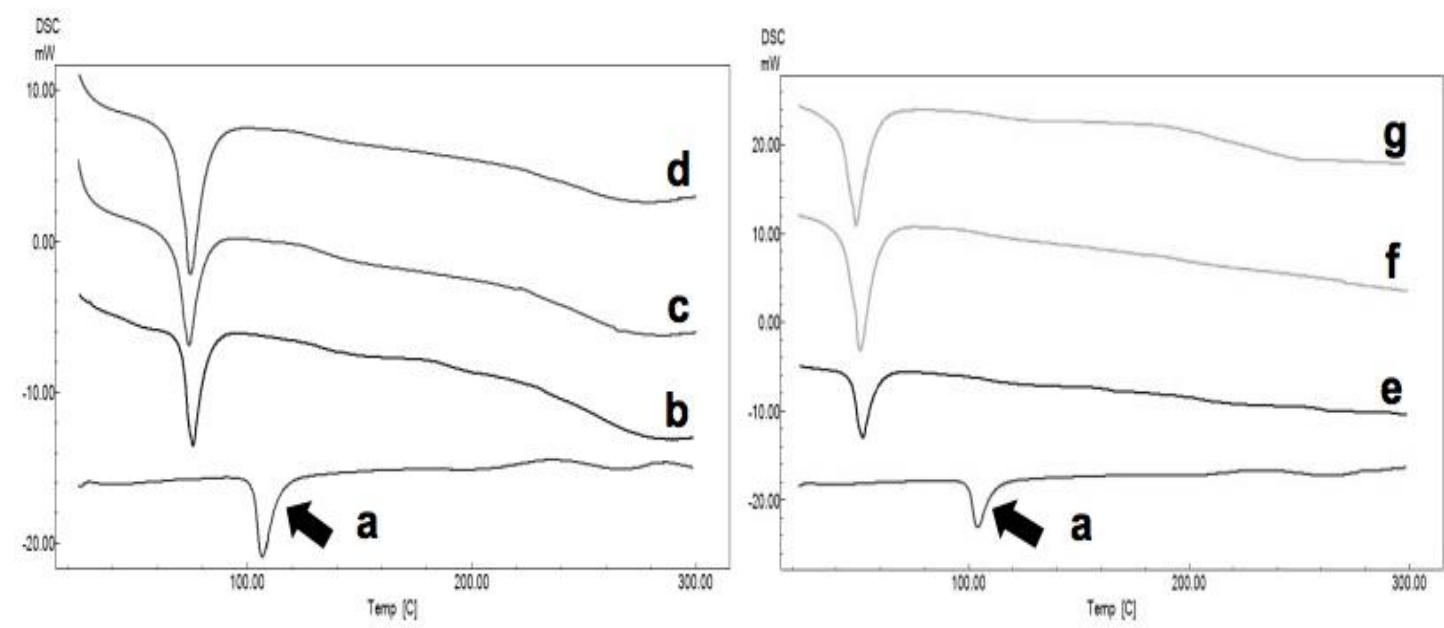

Figure 3. DSC thermograms of pure DT and SLN formulations, a: Pure DT, b: Compritol ${ }^{\circledR}$ ATO 888, c: COMP-E, d: COMP-DT, e: Dynasan ${ }^{\circledR} 114$, f: DYN-E, g: DYN-DT.

\subsubsection{X-ray diffractometry (XRD)}

XRD profiles of formulations are given in Figure 4. Based on the knowledge that reference and experimental DSC peaks both represent a family, crystal structures observed for pure Compritol ${ }^{\circledR} 888$ ATO and Dynasan ${ }^{\circledR} 114$ were found not to be degraded under SLN preparation conditions [23]. However, diffraction pattern and peak intensity values were reduced in the profiles of formulations prepared in parallel to the results in the literature [25]. In XRD profiles of SLN formulations, overlapping peaks at $2 \theta$ i.e. similar peaks with pure lipids showed that there were no changes in the structures of lipids due to preparation conditions. However, specific DT peaks were not observed in the XRD profiles of SLN formulations which may be due to the low concentration of DT [24]. Similar results were observed in the study of SLN formulations containing cyclosporine-A. It has been discussed that the cyclosporine-A peak cannot be detected in XRD models of formulations due to the low concentration of cyclosporine-A [24]. 

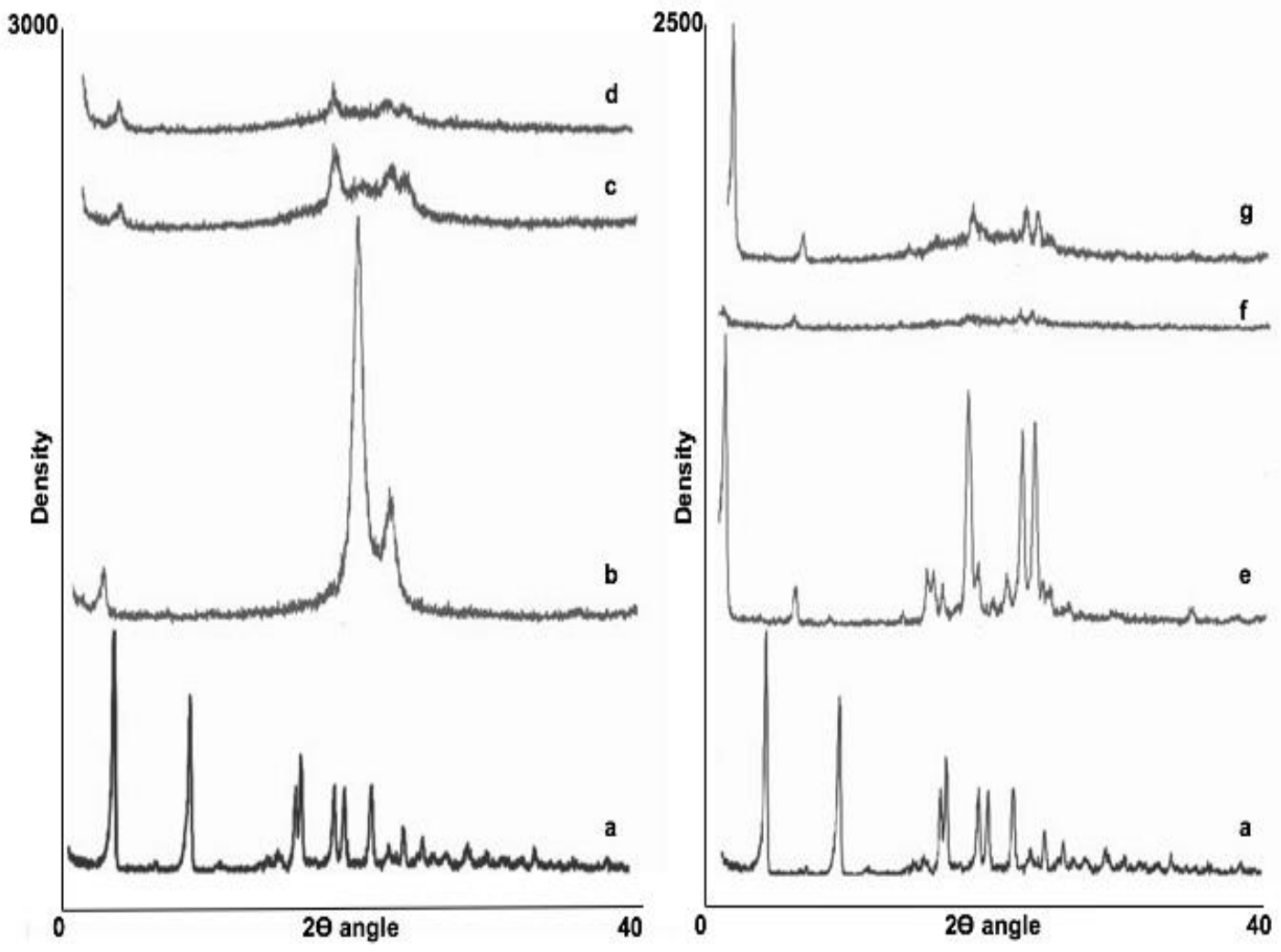

Figure 4. XRD profiles of pure DT and SLN formulations, a: Pure DT, b: Compritol ${ }^{\circledR}$ ATO 888, c: COMP-E, d: COMP-DT, e: Dynasan ${ }^{\circledR} 114$, f: DYN-E, g: DYN-DT.

\subsubsection{Fourier transform infrared spectrophotometry (FT-IR)}

FT-IR spectra of formulations are given in Figure 5. FT-IR analysis is performed to examine possible microstructural changes in the lipid structure and to prove that crystal structure is preserved. Identical FT-IR spectra of COMP-E and DYN-E with the pure solid lipid spectrum showed that preparation parameter of $60 \%$ amplitude probe sonication for $5 \mathrm{~min}$ did not alter solid lipid structure [26]. FT-IR spectra of COMP-DT and DYN-DT was found to be similar to FT-IR spectra of COMP-E, Compritol ${ }^{\circledR}$ ATO 888 and DYN-E and Dynasan ${ }^{\circledR}$ 114 , respectively. DT is characterized by an intense band at $1020 \mathrm{~cm}^{-1}$. Vibrations at $1571 \mathrm{~cm}^{-1}, 1536 \mathrm{~cm}^{-1}, 1020$ $\mathrm{cm}^{-1}, 881 \mathrm{~cm}^{-1}, 771 \mathrm{~cm}^{-1}$ and $641 \mathrm{~cm}^{-1}$ indicate the purity of DT [26]. Characteristic DT peaks were less intense in the FT-IR spectra of the physical mixtures. Compared with pure solid lipid, low density in some regions of FT-IR spectra of COMP-DT and DYN-DT were interpreted as new crystal lipid cages. Slight shifts in the functional groups and reduction in the densities of some peaks proved the presence of hydrogen $(\mathrm{H})$ bond between DT and solid lipid. In the light of the FT-IR spectra, no change was found in the lipid structures and DT was found to be encapsulated into solid lipids [24].

\subsubsection{Nuclear magnetic resonance (NMR)}

${ }^{1} \mathrm{H}-\mathrm{NMR}$ spectra of formulations are given in Figure 6. In this analysis, SLN formulations were lyophilized to remove water from the formulations in order to avoid ${ }^{1} \mathrm{H}-\mathrm{NMR}$ signals and then analyzed. When results of ${ }^{1} \mathrm{H}-\mathrm{NMR}$ analysis were evaluated, no significant difference between formulations without DT and pure lipid spectra was determined. Spectra showed clearly that there was no structural changes with the effect of other ingredients or preparation conditions. Characteristic DT peaks at 7-8 ppm appeared to be low in the spectra of COMP-DT and DYN-DT which was attributed to the low concentration in the formulations, however suggesting DT encapsulated into solid lipids [24, 26, 27]. 


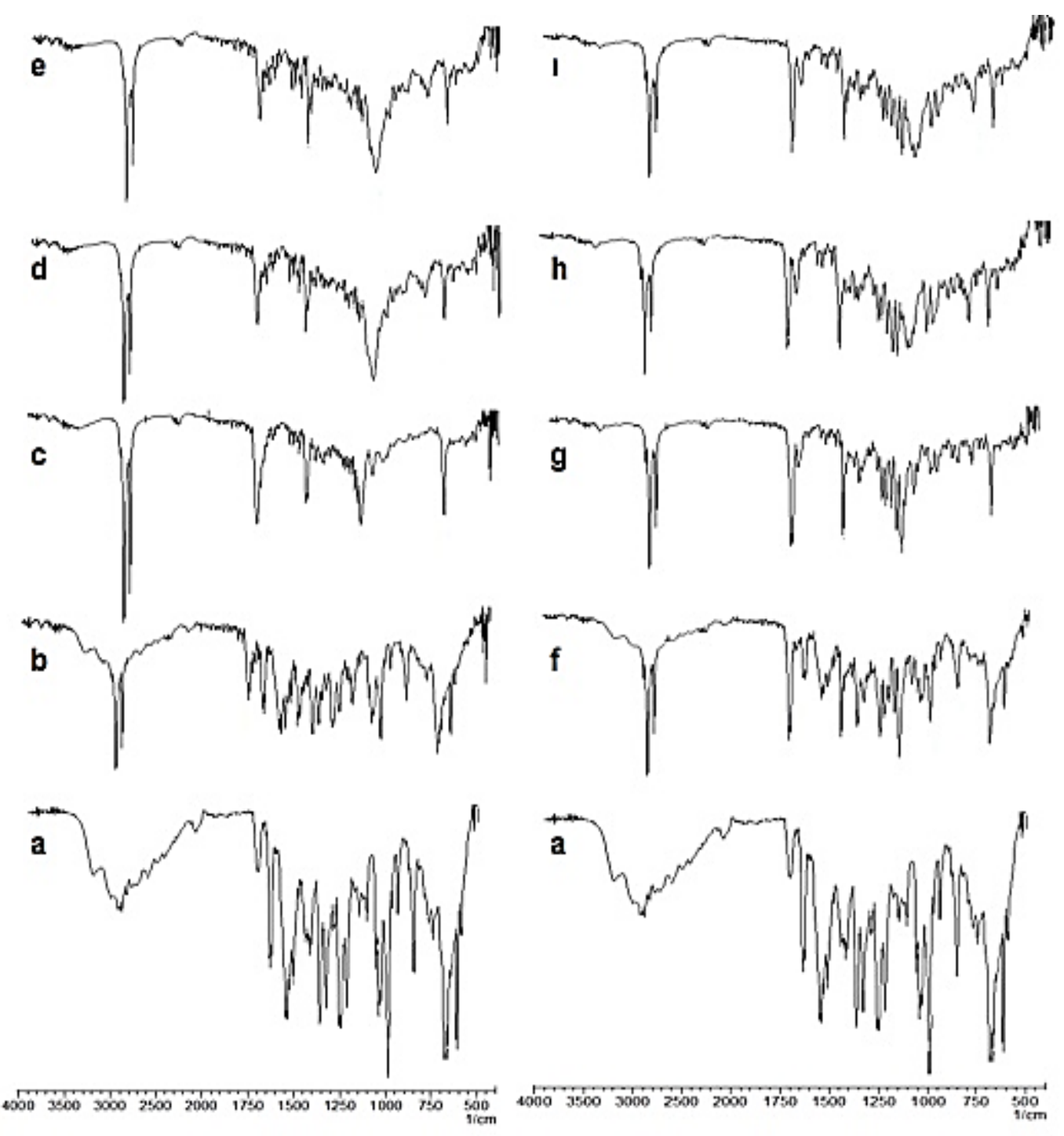

Figure 5. FT-IR spectra of DT, physical mixtures and SLN formulations a: Pure DT, b: Physical mixture (COMP and DT), c: Compritol ${ }^{\circledR}$ ATO 888, d: COMP-E, e: COMP-DT, f: Physical mixture (DYN and DT), g: Dynasan ${ }^{\circledR} 114$, h: DYN-E, i: DYN-DT.

\subsubsection{Drug loading efficiency}

HPLC method developed was validated for precision, accuracy, specificity and linearity. Linearity was determined to be at the concentration range of 10-80 $\mu \mathrm{g} \cdot \mathrm{mL}^{-1}$. The method developed for DT was decided to be precise due to RSD values of $<2 \%$ for repeatability and intermediate precision. Recovery of the method was satisfactory owing to $<2 \%$ RSD value. Conclusively, procedure proposed in this study can be used for routine, simultaneous and concurrent DT determination. Validation of the HPLC method used for the determination of DT was determined using $8\left(10 \mu \mathrm{g} \cdot \mathrm{mL}^{-1}, 20 \mu \mathrm{g} \cdot \mathrm{mL}^{-1}, 30 \mu \mathrm{g} \cdot \mathrm{mL}^{-1}, 40 \mu \mathrm{g} \cdot \mathrm{mL}^{-1}, \mu \mathrm{g} \cdot \mathrm{mL}^{-1}, 60 \mu \mathrm{g} \cdot \mathrm{mL}^{-1}, 70 \mu \mathrm{g} \cdot \mathrm{mL}^{-}\right.$ $\left.{ }_{1}^{1}, 80 \mu \mathrm{g} \cdot \mathrm{mL}^{-1}\right)$ different concentrations and DT showed a linearity of $\mathrm{y}=67363 \mathrm{x}-243811\left(\mathrm{r}^{2}=0\right.$ 9999) linearity, accuracy of $100.768 \% \pm 0.3975,99.964 \% \pm 0.439$ and $99.533 \% \pm 0.312$ for the concentrations of $20 \mu \mathrm{g}^{-\mathrm{mL}^{-1}, 40 \mu \mathrm{g} . \mathrm{mL}^{-}}$ ${ }^{1}$ and $60 \mu \mathrm{g} \cdot \mathrm{mL}^{-1}$, respectively $(\mathrm{n}=6)$. Limit of detection $(\mathrm{LOD})$ was determined to be $0.5613 \mu \mathrm{g} \cdot \mathrm{mL}^{-1}$ while limit of quantitation (LOQ) was $1.7010 \mu \mathrm{g} \cdot \mathrm{mL}^{-1}$.

Drug loading efficiency results are given in Table 1. Nanoparticles are particles composed of natural/synthetic polymers and lipids and which are smaller than $1000 \mathrm{~nm}$ [28]. Active ingredient may be present in the matrix or adsorbed onto its surface. Therefore, when analyzing the amount of active ingredient in the nanoparticle system, both the amount encapsulated and the amount adsorbed onto the lipid surface should be determined [28]. Loading efficiency of the COMP-DT and DYN-DT formulations was found to be 
$8.802 \% \pm 1.747$ (mean \pm SE) and $11.612 \% \pm 0.204$ (mean \pm SE), respectively. This is in agreement with the low loading capacity, which is one of the disadvantages of the SLN systems.

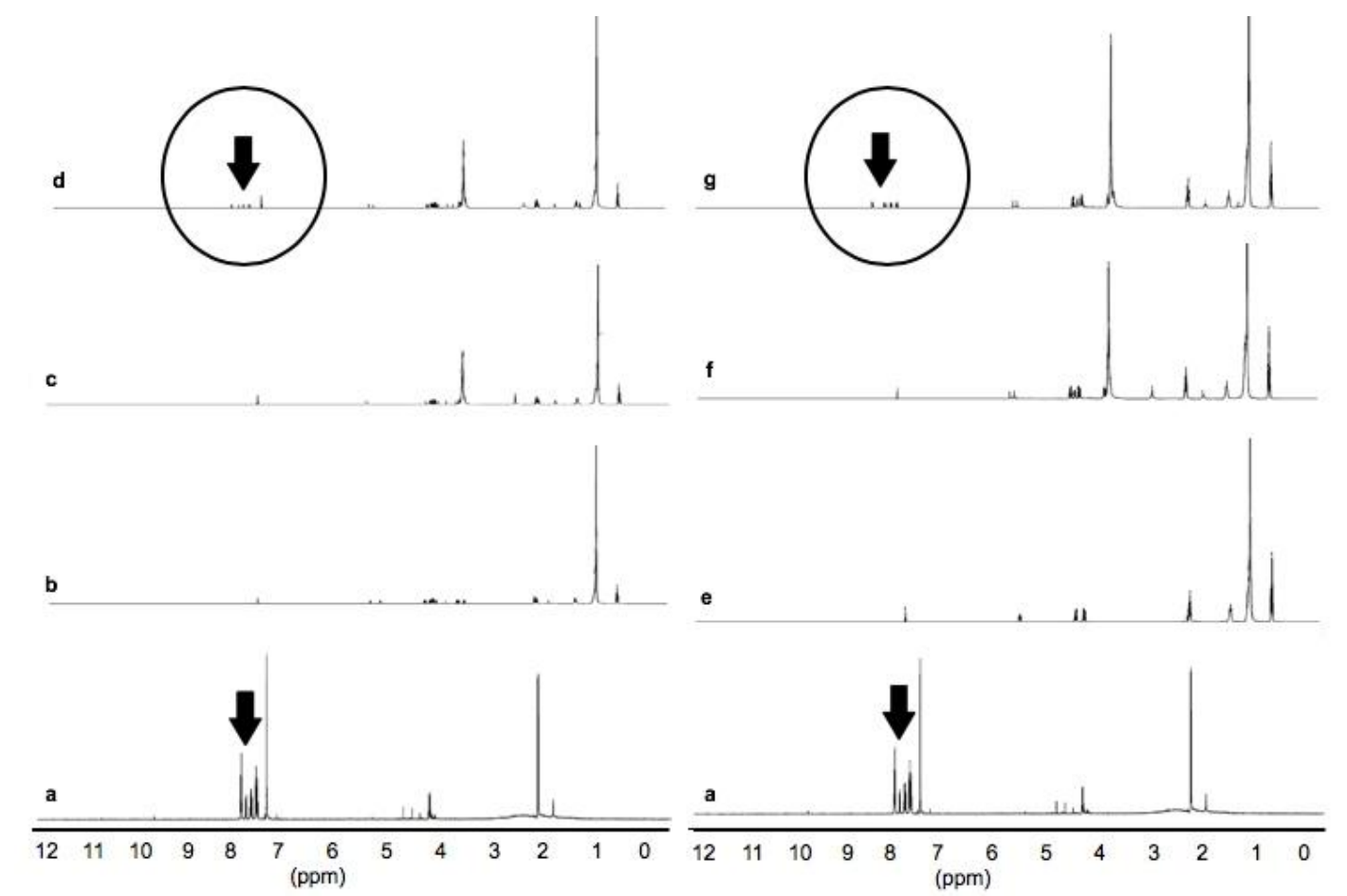

Figure 6. ${ }^{1} \mathrm{H}-\mathrm{NMR}$ spectra of pure DT and SLN formulations, a: Pure DT, b: Compritol ${ }^{\circledR}$ ATO 888, c: COMPE, d: COMP-DT, e: Dynasan ${ }^{\circledR} 114$, f: DYN-E, g: DYN-DT.

\subsubsection{In vitro release}

In vitro release studies play an important role in the formulation and quality control of drug delivery systems. In vitro release test results are used not only for monitoring the stability of the drugs but also for predicting the in vivo absorption of drugs. It is a much cheaper and faster method than expensive in vivo absorption studies. For this reason, in vitro release studies are frequently used and of great interest in the pharmaceutical field [29]. In vitro release profiles of pure DT and SLN formulations are presented in Figure 7 and also 2-hour release profiles are given in Figure 7 to provide a more detailed picture of the release in the first time interval. The fact that DT has a short half-life and rapid release from the commercial tablet formulation requires the patient to administer the drug at least three times a day. In this study, the aim of preparing SLN is to provide the initial dose with the amount of DT on the surface and the maintenance dose with DT loaded into the particles. Release of pure DT reached $92.217 \pm 0.682 \%$ (mean \pm SE) within the first two hours. On the contrary, it is clearly seen in the release profiles of SLN formulations that in vitro release is prolonged. Initial rapid release observed in SLN profiles is most probably due to dissolution of DT adsorbed on the particle surface and DT encapsulated was continuously released for 48 hours. DT released at the 48th hour from COMP-DT and DYN-DT was found to be $67.742 \% \pm 0.128$ (mean \pm SE) and $45.767 \% \pm 2.571$ (mean \pm SE), respectively. Among the SLN systems prepared COMP-DT seems to provide the intended activity considering the significance of proper release for orally administered nano-systems.

\subsubsection{Kinetics of in vitro release}

Significant progress was made over the past years in the design and use of controlled release forms instead of conventional dosage forms. Many medicinal active agents in the market have controlled release dosage forms. Most of the drugs are released from controlled systems at zero degree or first degree, or at zero or first order kinetics after a rapid release [30]. Drug release data are evaluated using many mathematical models and statistical parameters. Most of those models contain nonlinear equations. In order to overcome the absence of a program that uses mathematical models, difficulty of comparing profiles, many experimental errors and information from user error, researchers developed DDSolver program which can evaluate 40 different dissolution parameters in the evaluation of release data [29]. 
Kinetic modeling of in vitro release from COMP-DT and DYN-DT by DDSolver software program is given in Table 2. In this study, DDSolver program was used to shorten the calculation time, to eliminate calculation errors and to determine the correct release profile. When all SLN nanoparticles were analyzed for cumulative DT dissolution, they appeared to be released for 48 hours. After calculation, data transferred to DDSolver program to determine thee important criteria, rate constant $(\mathrm{k})$, Akaike information criteria (AIC) and coefficient of determination $\left(\mathrm{r}^{2}\right)$. The highest $\mathrm{k}$ and $\mathrm{r}^{2}$ values and the lowest AIC values were used for evaluation [31]. Zero-order kinetics, first-order kinetics, Higuchi, Hopfenberg, Hixon-Crowell and KorsmeyerPeppas models were selected for evaluation in DDSolver program.

It was determined that release profiles from COMP-DT and DYN-DT were in agreement with the Higuchi and Korsmeyer-Peppas models. Comparing those two models using the evaluation criteria, Korsmeyer-Peppas model was selected as the most suitable model. Korsmeyer-Peppas model is a model representing release in a controlled manner from a matrix system [30]. Therefore, it was concluded that SLN formulations which fit best to Korsmeyer-Peppas model are controlled release matrix systems.

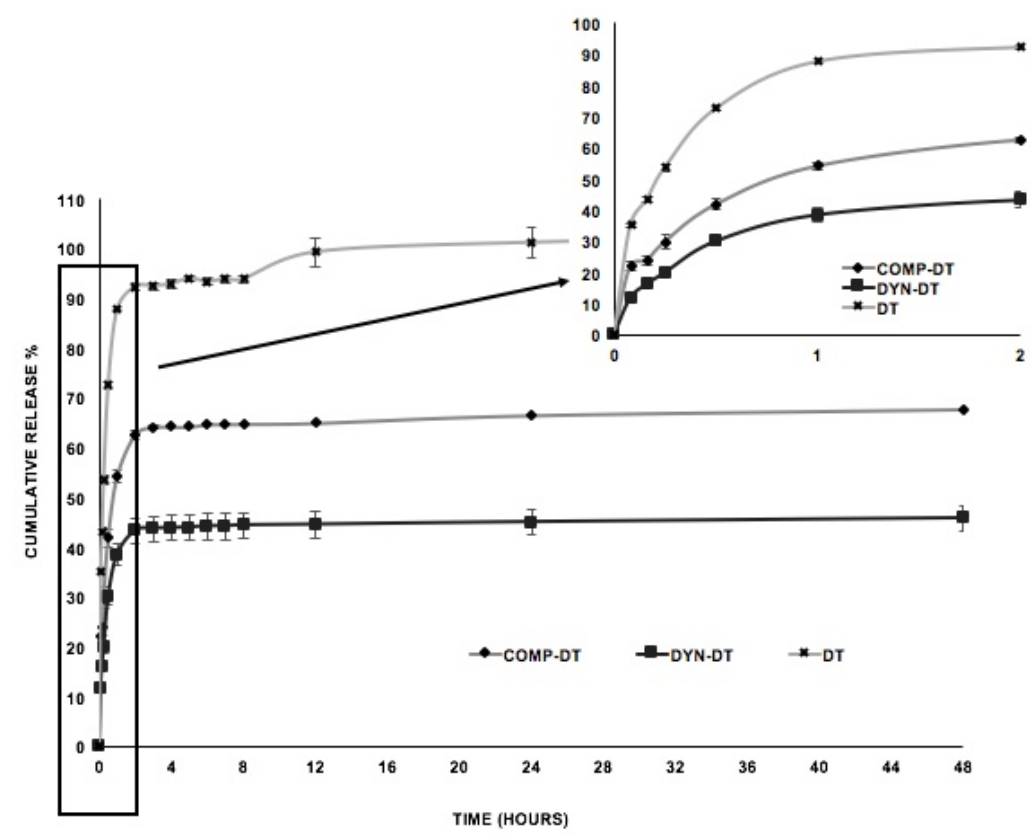

Figure 7. In vitro release profiles of pure DT and SLN formulations.

Table 2. Kinetic modeling of COMP-DT and DYN-DT by DDSolver program.

\begin{tabular}{lccc}
\hline Kinetic Model & Evaluation Criteria & COMP-DT & DYN-DT \\
\hline \multirow{3}{*}{ First order } & $\mathrm{k}$ & 2.469 & 1.677 \\
& $\mathrm{r}^{2}$ & -3.356 & -3.208 \\
& $\mathrm{AIC}$ & 166.406 & 154.388 \\
\hline \multirow{3}{*}{ Zero order } & $\mathrm{k}$ & 0.061 & 0.033 \\
& $\mathrm{r}^{2}$ & -1.632 & -2.120 \\
\hline \multirow{3}{*}{ Higuchi } & $\mathrm{AIC}$ & 158.343 & 149.601 \\
& $\mathrm{k}$ & 17.513 & 11.937 \\
& $\mathrm{r}$ & -0.739 & -0.699 \\
Hixson- Crowell & $\mathrm{AIC}$ & 151.710 & 139.882 \\
& $\mathrm{k}$ & 0.017 & 0.010 \\
& $\mathrm{r}$ & -1.922 & -2.403 \\
Hopfenberg & $\mathrm{AIC}$ & 160.017 & 150.995 \\
& $\mathrm{k}$ & 0.017 & 0.007 \\
& $\mathrm{r}$ & -1.922 & -2.326 \\
\hline \multirow{3}{*}{ Korsmeyer- Peppas } & $\mathrm{AIC}$ & 162.017 & 152.626 \\
& $\mathrm{k}$ & 43.133 & 28.645 \\
& $\mathrm{r}$ & 0.654 & 0.568 \\
\hline
\end{tabular}

${ }^{*} \mathbf{k}$ : release rate constant, $\mathbf{r}^{2}$ : coefficient of determination, AIC: Akaike criteria 


\subsubsection{Six month stability study of SLN formulation}

In this study, the COMP-DT coded formulation was chosen as the optimum formulation because it exhibited a more efficient release profile. Stability, cytotoxicity and in vivo animal experiments were performed on optimum formulation. Particle size, PDI, zeta potential and drug loading efficiency analysis were performed for COMP-DT in the stability studies. Particle size, polydispersity index, zeta potential and drug loading efficiency results obtained in stability study are given in Table 3.

Table 3. Particle size, polydispersity index, zeta potential and drug loading efficiency of COMP-DT in stability study.

\begin{tabular}{|c|c|c|c|c|c|}
\hline Temperature & Time & PS (nm) $\pm S E$ & $\mathrm{PDI} \pm \mathrm{SE}$ & $\mathrm{ZP} \pm \mathrm{SE}$ & $\mathrm{DL} \% \pm \mathrm{SE}$ \\
\hline \multirow{5}{*}{$4 \pm 1^{\circ} \mathrm{C}$} & Zero time & $100.410 \pm 1.820$ & $0.345 \pm 0.050$ & $-10.80 \pm 0.05$ & $8.802 \pm 1.747$ \\
\hline & $1^{\text {st }}$ month & $120.650 \pm 2.560$ & $0.363 \pm 0.061$ & $-13.25 \pm 0.15$ & $8.754 \pm 1.865$ \\
\hline & $2^{\text {nd }}$ month & $136.925 \pm 1.652$ & $0.345 \pm 0.054$ & $-14.25 \pm 0.74$ & $8.156 \pm 1.098$ \\
\hline & $3^{\text {rd }}$ month & $141.930 \pm 3.980$ & $0.398 \pm 0.054$ & $-13.62 \pm 1.20$ & $7.895 \pm 1.156$ \\
\hline & $6^{\text {th }}$ month & $190.862 \pm 1.265$ & $0.374 \pm 0.065$ & $-10.80 \pm 0.05$ & $8.050 \pm 1.440$ \\
\hline \multirow{5}{*}{$25 \pm 1^{\circ} \mathrm{C}$} & Zero time & $100.410 \pm 1.820$ & $0.345 \pm 0.050$ & $-10.80 \pm 0.05$ & $8.802 \pm 1.747$ \\
\hline & $1^{\text {st }}$ month & $129.617 \pm 1.560$ & $0.362 \pm 0.045$ & $-12.21 \pm 0.66$ & $8.658 \pm 1.560$ \\
\hline & $2^{\text {nd }}$ month & $138.315 \pm 4.356$ & $0.391 \pm 0.064$ & $-12.85 \pm 0.74$ & $8.703 \pm 1.445$ \\
\hline & $3^{\text {rd }}$ month & $150.625 \pm 3.650$ & $0.415 \pm 0.068$ & $-10.75 \pm 1.05$ & $8.025 \pm 1.756$ \\
\hline & $6^{\text {th }}$ month & $170.674 \pm 2.689$ & $0.365 \pm 0.075$ & $-14.25 \pm 0.85$ & $7.789 \pm 1.978$ \\
\hline \multirow{5}{*}{$40 \pm 1^{\circ} \mathrm{C}$} & Zero time & $100.410 \pm 1.820$ & $0.345 \pm 0.050$ & $-10.80 \pm 0.05$ & $8.802 \pm 1.747$ \\
\hline & $1^{\text {st }}$ month & $136.700 \pm 4.235$ & $0.485 \pm 0.055$ & $-10.95 \pm 0.25$ & $8.652 \pm 1.158$ \\
\hline & $2^{\text {nd }}$ month & $158.501 \pm 3.650$ & $0.396 \pm 0.078$ & $-13.6 \pm 1.06$ & $7.778 \pm 1.658$ \\
\hline & $3^{\text {rd }}$ month & $197.202 \pm 2.655$ & $0.370 \pm 0.064$ & $-13.69 \pm 1.15$ & $7.798 \pm 1.008$ \\
\hline & $6^{\text {th }}$ month & $220.311 \pm 1.844$ & $0.416 \pm 0.085$ & $-12.25 \pm 0.95$ & $7.654 \pm 1.068$ \\
\hline
\end{tabular}

*PS: Particle size, PDI: Polydispersity index, ZP: Zeta potential, DL\%: Drug loading efficiency, SE: Standard error

Freshly prepared COMP-DT coded formulation showed $100.410 \pm 1.820 \mathrm{~nm}$ mean particle size [PDI $=$ $0.345 \pm 0.050]$. Mean particles sizes and PDI values at the end of the 6 months were $190.862 \pm 1.265 \mathrm{~nm}(\mathrm{p}<0.05)$ [PDI=0.374 \pm 0.065$], 170.674 \pm 2.689 \mathrm{~nm}(\mathrm{p}<0.05) \quad[\mathrm{PDI}=0.365 \pm 0.075]$ and $220.311 \pm 1.844 \mathrm{~nm}(\mathrm{p}<0.01)$ [0.416 \pm 0.085$]$ for the formulations kept at $4{ }^{\circ} \mathrm{C} \pm 1{ }^{\circ} \mathrm{C}, 25^{\circ} \mathrm{C} \pm 1{ }^{\circ} \mathrm{C}$ and $40^{\circ} \mathrm{C} \pm 1{ }^{\circ} \mathrm{C}$, respectively. Despite the variation of particle sizes DT loaded SLN formulation remained in the nanometer range with narrow size distribution after 6 months [32]. The PDI values of COMP-DT coded KLN formulation were determined to be less than 0.7 during the stability period and it was concluded that uniform distribution was maintained. COMP-DT, freshly prepared formulation had $-10.80 \pm 0.05 \mathrm{mV}$ zeta potential value. At the end of 6 months, zeta potentials $13.75 \pm 1.15 \mathrm{mV}(\mathrm{p}>0.05),-14.25 \pm 0.85 \mathrm{mV}(\mathrm{p}>0.05)$ and $12.25 \pm 0.95 \mathrm{mV}(\mathrm{p}>0.05)$ for the formulations kept at $4{ }^{\circ} \mathrm{C} \pm 1{ }^{\circ} \mathrm{C}, 25^{\circ} \mathrm{C} \pm 1{ }^{\circ} \mathrm{C}$ and $40^{\circ} \mathrm{C} \pm 1{ }^{\circ} \mathrm{C}$, respectively. As a result, it was determined that zeta potential of SLN formulation remained at negative values after 6 months [32]. DT content in freshly prepared SLN formulation was determined to be $8.802 \pm 1.747$ (\% content \pm SE). Drug loadings at the end of 6 months were $8.050 \pm 1.440(\mathrm{p}>0.05), 7.789 \pm 1.978(\mathrm{p}>0.05)$ and $7.654 \pm 1.068(\mathrm{p}>0.05)$ for the formulations kept at $4{ }^{\circ} \mathrm{C} \pm 1{ }^{\circ} \mathrm{C}, 25^{\circ} \mathrm{C} \pm 1{ }^{\circ} \mathrm{C}$, and $40^{\circ} \mathrm{C} \pm 1^{\circ} \mathrm{C}$, respectively (Table 4). There seems to be no significant changes in DT content under different stability conditions.

\subsection{Cytotoxicity}

Cytotoxicity was investigated in a wide range of concentration from $0.05 \mu \mathrm{g} .100 \mu \mathrm{L}^{-1}$ to $100 \mu \mathrm{g} .100 \mu \mathrm{L}^{-1}$. Cytotoxicity's of all SLN formulations with respect to time and concentration are given in Figure 9 together with their standard deviation ( \pm ) values. IC 50 values were determined to be $75 \mu \mathrm{g} .100 \mu \mathrm{L}^{-1}$ at 24 hours and 25 $\mu \mathrm{g} .100 \mu \mathrm{L}^{-1}$ at 48 hours only in DT treated wells. $\mathrm{IC}_{50}$ value of COMP-E formulation was determined to be 7 $\mu \mathrm{g}-100 \mu \mathrm{L}^{-1}$ at 24 hours while this value decreased to $5 \mu \mathrm{g} .100 \mu \mathrm{L}^{-1}$ at 48 hours. For COMP-DT, IC 50 value was 
determined to be $25.93 \mu \mathrm{g}-100 \mu \mathrm{L}^{-1}$ after 24 -hour incubation and this value was found to be $11.71 \mu \mathrm{g} .100 \mu \mathrm{L}^{-1}$ after 48-hour incubation.

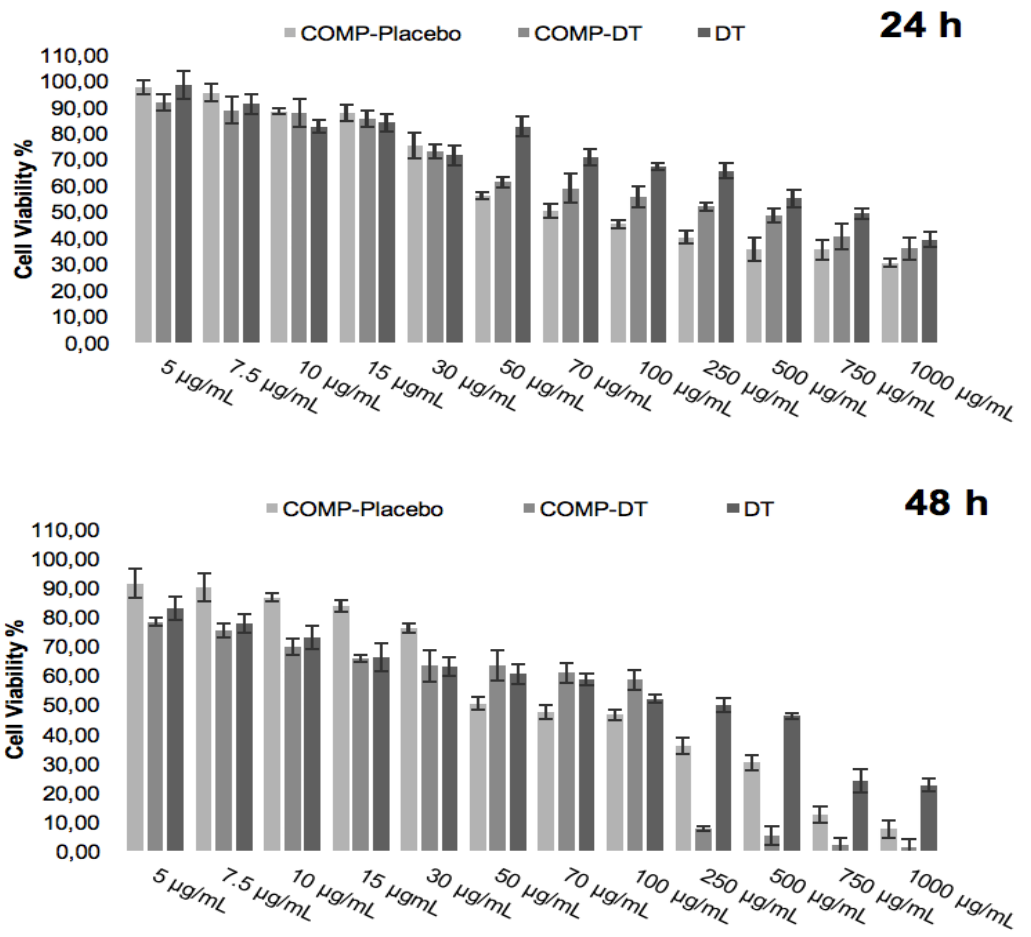

Figure 8. Cell viability of SLN formulations prepared.

In this study, MTT assay was used to determine cytotoxicity's of all formulations. This test develops a quantitative colorimetric assay via tetrazolium salt of mammalian cell survival and proliferation. It detects living cells, not dead cells, and viability depends on the degree of activation of signaling cells produced. Studies with Compritol ${ }^{\circledR}$ are available in the literature $[33,34,35]$. In a study, $\mathrm{IC}_{50}$ value at 72 hours was determined as $471.48 \mu \mathrm{g} \cdot \mathrm{mL}^{-1}$ for Compritol ${ }^{\circledR}$ SLNs with no active ingredient [36]. In the only study with DT, significant cytotoxicity and reduction in cell proliferation at 24, 48 and 72 hours were shown in vitro on primer chondrocytes compared to control cells not treated with DT [37].

In this study, $\mathrm{IC}_{50}$ value of COMP-E was found to be lower than that of nanoparticles containing DT after 24 hours of incubation. This suggests that DT is also localized on the lipid particles during SLN preparation and that it is first solubilized before solid lipid in the cell culture. Therefore, toxicity is thought to be low due to less toxicity of DT. Higher cytotoxicity as time progresses may be attributed to disintegration of formulations and the resulting residues.

\subsection{In vivo study}

In vivo study results of COMP-DT are given in Figure 9. Figure 9 shows the results of the hot plate test conducted to evaluate the analgesic activity of DT and COMP-DT. When the analgesic efficacy of COMP-DT containing $10 \mathrm{mg} \cdot \mathrm{kg}^{-1}$ of DT and $10 \mathrm{mg} \cdot \mathrm{kg}^{-1}$ of DT alone was compared with the control group (physiological saline/serum physiologique: SP), statistically significant difference between DT and the control group was determined at the $1^{\text {st }}$ hour $(p<0.01)$ while no significant difference was found at the $3^{\text {rd }}, 6^{\text {th }}$ and $9^{\text {th }}$ hours. However, DT was relatively effective at the $3^{\text {rd }}$ hour. Comparing analgesic activity of COMP-DT and the control group, significant difference was determined at all hours $\left(1^{\text {st }} h ., p<0.001 ; 3^{\text {rd }} h ., p<0.001 ; 6^{\text {th }} h ., p<0.001\right.$; $9^{\text {th }} \mathrm{h} ., \mathrm{p}<0.05$ ) (Figure 9). This may be explained by the smaller size and presence of higher amount of superficial DT of COMP-DT which can easily be transferred to the central nervous system and exert significant analgesic efficacy. Comparison of analgesic activities of COMP-DT and DT showed no significant difference at the $1^{\text {st }}$ and $3^{\text {rd }}$ hours but significant difference $(p<0.001)$ at the $6^{\text {th }}$ and $9^{\text {th }}$ hours. Conclusively, data obtained in the hot plate test demonstrated maximal activity of pure DT at the $1^{\text {st }}$ hour with decrease in antinociceptive effect at the other testing times while all formulations maintained their analgesic activities up to 9 hours. 
In the tail immersion test, analgesic efficacies of COMP-DT containing $10 \mathrm{mg} \cdot \mathrm{kg}^{-1} \mathrm{DT}$ and $10 \mathrm{mg} \cdot \mathrm{kg}^{-1}$ pure DT was compared first with the control group (SP) and then with pure DT (Figure 9). Pure DT and control group were found to be statistically different $(p<0.05)$ at the $1^{\text {st }}$ hour while there was no significant difference at the $3^{\text {rd }}, 6^{\text {th }}$ and $9^{\text {th }}$ hours, as in the hot plate test. Maximum analgesic efficacy of DT was at the $1^{\text {st }}$ hour, decreasing gradually and disappearing at the following hours. When the analgesic efficacy of COMP-DT was compared with the control group, analgesic effect was observed at all time intervals. However, it presented relatively high analgesic effect $(\mathrm{p}<0.001)$ only at the $6^{\text {th }}$ hour. Comparison of analgesic activities of COMP-DT and pure DT, showed no significant difference at the $1^{\text {st }}$ hour but significant differences at all other hours $\left(6^{\text {th }}\right.$ $h, p<0.001 ; 9^{\text {th }} h, p<0.05$ ) (Figure 9). As a result of tail immersion test, it was found that pure DT with maximal effect at the $1^{\text {st }}$ hour gradually lost its effect while COMP-DT showed analgesic activity even at the $9^{\text {th }}$ hour.
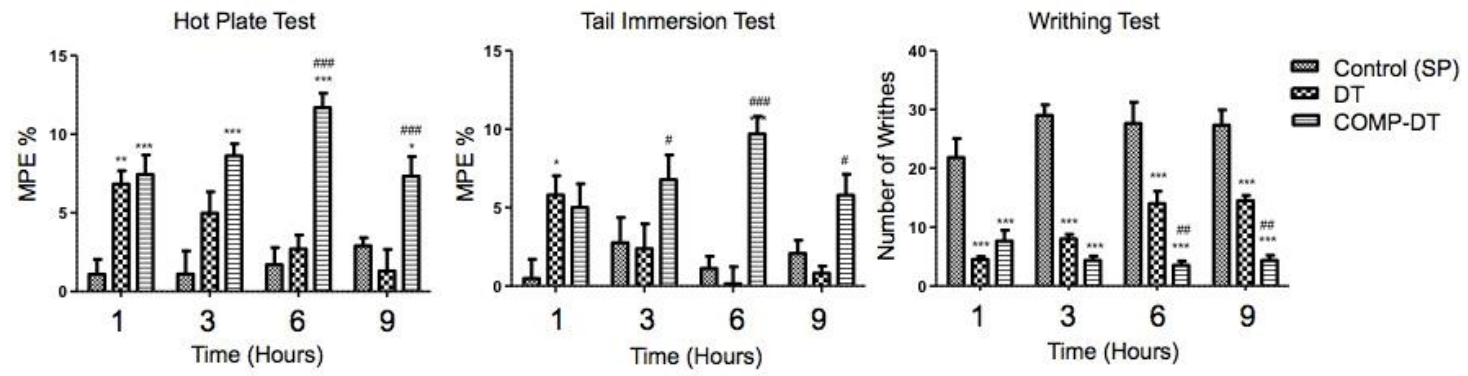

Figure 9. In vivo test results of COMP-DT, *Comparison with SP, \#Comparison with DT .

Writhing test which is used for evaluating analgesic activity at the peripheral level demonstrated significant difference $(p<0.001)$ between the control group and both pure DT and COMP-DT at all times up to 9 hours (Figure 9). There was no significant difference between the peripheral analgesic effects of pure DT and COMP-DT at the $1^{\text {st }}$ and $3^{\text {rd }}$ hours while significant difference was found at the $6^{\text {th }}$ and $9^{\text {th }}$ hours $\left(6^{\text {th }} \mathrm{h}, \mathrm{p}<0.001\right.$; $\left.9^{\text {th }} \mathrm{h}, \mathrm{p}<0.001\right)$. Conclusively, pure DT provided maximum efficacy at the $1^{\text {st }}$ hour with decrease at all other times, however COMP-DT demonstrated sustained peripheral analgesic activity pattern at all testing times.

When all the in vivo results obtained were evaluated together, it was observed that both the central and peripheral analgesic effects of COMP-DT were similar to each other while the effect of pure DT decreased after the $1^{\text {st }}$ hour. Similar activities of pure DT and COMP-DT at the $1^{\text {st }}$ hour may be attributed to DT adsorbed onto the particle surface during preparation which dissolves rapidly in the in vivo environment exerting its analgesic effect. It was also determined that DT incorporated into SLNs maintained analgesic activity up to 9 hours which indicated sustained pattern.

\subsection{Dexketoprofen trometamol loaded nano-system studies}

When literature review is performed, it is seen that there are studies of nanoparticles containing DT. In one of these studies, spray dried nanoparticles were obtained using Eudragit RS 100 and Kollidon SR polymers [4]. In a similar study, the same technique but a different polymer, Eudragit RL 100, was used [2] Another DTcontaining study in the literature is PLGA nanoparticles prepared by double emulsion solvent evaporation method [26]. When these studies were examined, oral administration was aimed as in this SLN study and promising results were obtained. There are some differences in both this study and previous studies compared to each other. When particle sizes are examined; smaller particle sizes were obtained with SLN and PLGA nanoparticles. Previous studies and this study were evaluated in terms of drug loading and release; PLGA nanoparticle study can be said to be the most optimal study.

\section{CONCLUSION}

In this study, Compritol ${ }^{\circledR}$ ATO 888 and Dynasan ${ }^{\circledR} 114$ solid lipid nanoparticles were prepared aiming prolonged analgesic activity of dexketoprofen trometamol. Dexketoprofen trometamol loaded solid lipid nanoparticles were successfully prepared by the probe sonication method. Dexketoprofen trometamol-loaded solid lipid nanoparticles exhibited nanostructures while in vitro release showed sustained release of Dexketoprofen trometamol. Particle size of nanoparticles obtained were in the range of 92-137 nm. Low drug loading efficiencies (\%) were obtained (8-12\%) for all formulations prepared. Following oral administration of dexketoprofen trometamol-loaded Compritol ${ }^{\circledR}$ ATO 888 solid lipid nanoparticles to mice, both central and peripheral analgesic effects were found to be extended in comparison to pure DT. 


\section{MATERIALS AND METHODS}

\subsection{Materials}

Dexketoprofen trometamol was a kind gift from Abdi İbrahim (Istanbul, Turkey). Compritol ${ }^{\circledR}$ ATO 888 (Glyceryl behenate) and Dynasan ${ }^{\circledR} 114$ (Trimyristin) were products of Gattefosse (France) and Sasol (Germany), respectively. Methanol, dimethyl sulfoxide and deuterated chloroform were all purchased from Merck (Germany). Acetonitrile, potassium phosphate monobasic and sodium hydroxide were obtained from Sigma-Aldrich (Germany). All other chemicals and reagents used were of pharmaceutical and analytical grade.

\subsection{Methods}

\subsubsection{Pre-formulation and formulation of SLN}

Different solid lipid-surfactant ratios were tested using the same probe sonication (Sonics ${ }^{\circledR}$, USA) powers $(60 \%)$ to decide the optimum SLN formulations [38, 39]. Preformulation studies were performed with formulations containing 5-10\% Compritol ${ }^{\circledR}$ ATO 888, 1-10\% Tween ${ }^{\circledR} 80$ and 80-94\% distilled water. Briefly explaining, solid lipid was heated to a temperature $10^{\circ} \mathrm{C}$ above its melting point and mixed with the aqueous phase containing the surfactant which was also heated to the same temperature. 5 min probe sonication at $60 \%$ amplitude was applied on formulations. The same procedure explained above was performed for Dynasan ${ }^{\circledR}$ 114.

Once the procedure parameters were decided, different formulations with no DT but containing different ingredient ratios were prepared and tested for their particle size and zeta potential values. Ingredient ratios of the optimal blank formulation are given in Table 3.

Table 3. Blank SLN Formulations.

\begin{tabular}{|c|c|c|c|}
\hline $\begin{array}{c}{\text { Compritol }{ }^{\circledR} \text { ATO }}_{888(\% \mathrm{w} / \mathrm{w})}\end{array}$ & $\begin{array}{c}\text { Dynasan }^{\circledR} 114 \\
(\% \mathrm{w} / \mathrm{w})\end{array}$ & $\begin{array}{c}\text { Tween }^{\circledR} 80 \\
(\% \text { w/w })\end{array}$ & $\begin{array}{c}\text { Distilled water } \\
(\% \mathrm{w} / \mathrm{w})\end{array}$ \\
\hline 5 & - & 5 & 90 \\
\hline 5 & - & 4 & 91 \\
\hline- & 5 & 5 & 90 \\
\hline - & 5 & 4 & 91 \\
\hline
\end{tabular}

\subsubsection{DT-loaded SLN formulation}

SLN formulation containing DT was prepared just like the blank SLN formulation with DT addition to molten lipid. Formulation prepared was sonicated for $5 \mathrm{~min}$ at $60 \%$ power and left to cool down at room temperature. The same procedure was performed for Compritol ${ }^{\circledR}$ ATO 888 and Dynasan ${ }^{\circledR} 114$. SLN formulations containing DT are presented in Table 4. Particle size, polydispersity index and zeta potential measurements were achieved following preparation of DT formulations containing DT and the optimum formulations to be used in further studies were selected. Optimum blank and DT-loaded SLN formulations selected are given in Table 5.

Table 4. SLN formulations containing DT.

\begin{tabular}{ccccc}
\hline $\begin{array}{c}\text { Compritol }{ }^{\circledR} \mathbf{A T O} 888 \\
(\mathbf{\%} \mathbf{w} / \mathbf{w})\end{array}$ & $\begin{array}{c}\text { Dynasan }^{\circledR} \mathbf{1 1 4} \\
(\mathbf{\%} \mathbf{w} / \mathbf{w})\end{array}$ & $\begin{array}{c}\mathbf{D T} \\
(\mathbf{\%} \mathbf{w} / \mathbf{w})\end{array}$ & $\begin{array}{c}\text { Tween }^{\circledR} \mathbf{8 0} \\
(\mathbf{\%} \mathbf{w} / \mathbf{w})\end{array}$ & $\begin{array}{c}\text { Distilled water } \\
(\mathbf{\%} \mathbf{w} / \mathbf{w})\end{array}$ \\
\hline 5 & - & 0.5 & 5 & 89.5 \\
4.5 & - & 0.5 & 5 & 90 \\
\hline 5 & - & 0.5 & 4 & 90.5 \\
4.5 & - & 0.5 & 4 & 91 \\
\hline- & 5 & 0.5 & 5 & 89.5 \\
- & 4.5 & 0.5 & 5 & 90 \\
- & 5 & 0.5 & 4 & 90.5 \\
- & 4.5 & 0.5 & 4 & 91 \\
\hline
\end{tabular}


Table 5. Optimum blank and DT-loaded SLN formulations.

\begin{tabular}{|c|c|c|c|c|c|}
\hline Code* & $\begin{array}{c}\text { Compritol }^{\circledR} \text { ATO } 888 \\
(\% w / w)\end{array}$ & $\begin{array}{c}\text { Dynasan }^{\circledR} 114 \\
(\% \mathrm{w} / \mathrm{w})\end{array}$ & $\begin{array}{c}\text { DT } \\
(\% w / w)\end{array}$ & $\begin{array}{c}\text { Tween }^{\circledR} 80 \\
(\% w / w)\end{array}$ & $\begin{array}{c}\text { Distilled water } \\
(\% \mathrm{w} / \mathrm{w})\end{array}$ \\
\hline COMP-E & 5 & - & - & 5 & 90 \\
\hline COMP-DT & 5 & - & 0.5 & 5 & 89.5 \\
\hline DYN-E & - & 5 & - & 5 & 90 \\
\hline DYN-DT & - & 5 & 0.5 & 5 & 89.5 \\
\hline
\end{tabular}

*COMP-E: Formulation with Compritol ${ }^{\circledR}$ ATO 888 without active ingredient, COMP-DT: Formulation with Compritol ${ }^{\circledR}$ ATO 888 and active ingredient, DYN-E: Formulation with Dynasan ${ }^{\circledR} 114$ without active ingredient, DYN-DT: Formulation with Dynasan ${ }^{\circledR} 114$ and active ingredient,

\subsection{Characterization}

\subsubsection{Particle size, polydispersity index and zeta potential}

Particle size and distribution of SLN formulations prepared were measured by dispersing in distilled water. Particle size and distribution values were determined using a Zetasizer Nano ZS (Malvern, UK) instrument.

Zetasizer Nano ZS (Malvern, UK) instrument was used also to determine the zeta potential values of SLN formulations. Measurements were carried out in a disposable folded capillary zeta cell at $25^{\circ} \mathrm{C}$ room temperature after dilution with distilled water.

\subsubsection{Morphology}

Particle shape and surface properties of freshly prepared SLN formulations were determined using SEM (Scanning Electron Microscope) (Zeiss Ultra Plus Fesem, Germany) after spreading samples on carbon tape and coating with gold.

\subsubsection{Differential scanning calorimetry (DSC)}

Pressure-assisted aluminum sample vessel, nitrogen gas flow rate of $50 \mathrm{~mL} \cdot \mathrm{min}^{-1}$, temperature increase rate of $10^{\circ} \mathrm{C} \cdot \mathrm{min}^{-1}$ in $30-300^{\circ} \mathrm{C}$ range and an aluminum reference were employed for thermal analyses of SLN formulations using DSC (Schimadzu DSC-60, Japan).

\subsubsection{X-ray diffractometry $(X R D)$}

XRD analyses of the lyophilized SLN formulations and pure material were performed with a Rikagu generator (XRD Rikagu Rint 2000, Japan) at a speed of $40 \mathrm{kV}, 30 \mathrm{~mA}$ current intensity, $2 \theta$ angle and at a speed of $2^{\circ} / \mathrm{min}^{-1}$ in $2-40^{\circ}$ range.

\subsubsection{Fourier transform infrared spectrophotometry (FT-IR)}

FT-IR spectra of lyophilized SLN formulations were determined by FT-IR (Schimadzu IR Prestige-21, Japan) instrument at 4000-500 $\mathrm{cm}^{-1}$ wavelengths. The lyophilized SLN formulations and pure material were placed with directly on the relevant section of the FT-IR device.

\subsubsection{Nuclear magnetic resonance (NMR)}

NMR analyses ( $\left.{ }^{1} \mathrm{H}-\mathrm{NMR}\right)$ of the $10 \mathrm{mg}$ lyophilized SLN formulations prepared and pure material were achieved by dissolving in $500 \mu \mathrm{L}$ deutero chloroform $\left(\mathrm{CDCl}_{3}\right.$ ) using NMR (Bruker $500 \mathrm{MHz}$ Ultra Shield ${ }^{\mathrm{TM}}$ NMR, Germany) instrument. Solution prepared in tubes specially manufactured for NMR instrument.

\subsubsection{Drug loading efficiency}

HPLC (Shimadzu-20 A, Japan) was used with reversed-phase NUKLEODUR column $(4.6 \mathrm{~mm} \times 250 \mathrm{~mm}$, $\mathrm{C}_{18}$ Gravity, $\left.5 \mu \mathrm{m}\right)$ for the determination of DT using a modified method. 25:75 (v/v) acetonitrile-methanol was used as the mobile phase following preliminary tests for the best resolution of DT. Flow rate of the mobile phase was $1 \mathrm{~mL} \cdot \mathrm{min}^{-1}$ and a constant amount of $25 \mu \mathrm{L}$ was injected via an automatic injector (Shimadzu, Japan). Fluorescent detector (Shimadzu, Japan) was used at $258 \mathrm{~nm}$ and the column temperature was set to $30^{\circ} \mathrm{C}$. HPLC method used was validated $[40,41]$.

Dynasan $^{\circledR} 114$ is slightly soluble in n-hexane and diethyl ether while Compritol ${ }^{\circledR}$ ATO 888 is soluble in methylene chloride, chloroform and dichloromethane but insoluble in alcohol derivatives and water [42, 43]. 
For SLN formulations, mobile phase was used as the solvent in which DT dissolved but neither Compritol ${ }^{\circledR}$ ATO 888 nor Dynasan ${ }^{\circledR} 114$ dissolved in order to determine the amount of DT adsorbed onto the surface. $5 \mathrm{mg}$ formulation was put in Eppendorf tube and $2 \mathrm{~mL}$ of mobile phase was added. After keeping in ultrasonic bath for $5 \mathrm{~min}$, the upper transparent portion was centrifuged for $10 \mathrm{~min}$ at $11.000 \mathrm{rpm}$ and then filtered through polyamide filter and analyzed after dilution.

Analysis of the encapsulated DT was carried out using the method described in the literature [24]. $2 \mathrm{~mL}$ of mobile phase was added to the remaining particles. The structure of the SLN formulation deteriorated by standing for 15 minutes at $80-85^{\circ} \mathrm{C}$, in the ultrasonic bath. Immediately after heating, Eppendorf tube was deep frozen at a temperature of $-18 \pm 1^{\circ} \mathrm{C}$ and solid lipid was precipitated. Following this process, the supernatant solution was centrifuged at $11.000 \mathrm{rpm}$ for $10 \mathrm{~min}$ and then filtered through polyamide filter and analyzed after dilution to determine the amount of DT entrapped. The experiment was repeated 3 times. Equation 1 was used to calculate the drug loading efficiency (DL\%) [44].

$$
D L \%=\left[\frac{D T \text { in formulation }-D T \text { in supernatant }}{D T \text { in formulation }}\right] \times 100
$$

\subsubsection{In vitro release}

In vitro release of DT from SLN formulations were investigated over $48 \mathrm{~h}$ using a dialysis membrane. COMP-DT and DYN-DT formulations equivalent to $1 \mathrm{mg}$ of DT was placed in the cellulose acetate dialysis bag (with a MW of 12-14 kDa, Sigma), $1 \mathrm{~mL}$ of dissolution media was added and the bag was then sealed at both ends. Dialysis bag was then placed into an amber glass beaker containing $100 \mathrm{~mL}$ of PBS (pH 7.4) as the dissolution medium at $37^{\circ} \mathrm{C} \pm 0.5^{\circ} \mathrm{C}$ while stirring continuously at $100 \mathrm{rpm}$. The receptor compartment was closed to prevent evaporation of the dissolution medium. Samples $(1 \mathrm{~mL})$ were withdrawn at regular time intervals and the same volume $(1 \mathrm{~mL})$ was replaced by fresh dissolution medium. Samples were then tested by the validated HPLC method.

\subsubsection{Kinetics of in vitro release}

To determine the release kinetics, data obtained from in vitro drug release studies in phosphate buffer ( $\mathrm{pH}$ 7.4) were analyzed by a software program DDSolver [29].

\subsubsection{Six month stability study of SLN formulation}

The storage stability of DT loaded SLN formulation was followed to ICH Q1(R2) at $4 \pm 1^{\circ} \mathrm{C}, 25 \pm 1^{\circ} \mathrm{C}$ and $40 \pm 1^{\circ} \mathrm{C}$ up to six-months. In the stability studies; particle size, PDI, , zeta potential and drug loading efficiency were examined at certain time intervals. The characterizations in stability study were made as described in the upper section [32].

\subsection{Cytotoxicity}

\subsubsection{Cell culture}

The NIH/3T3 mouse embryonic fibroblast cells were obtained from the American Type Culture Collection (ATCC, USA). Cells were incubated in Dulbecco's modified Eagle's medium (DMEM) supplemented with 10\% fetal bovine serum (Sigma Aldrich, Germany) and penicillin-streptomycin (10.000 U penicillin and $10 \mathrm{mg}$ streptomycin. $\mathrm{mL}^{-1}$ ) (Sigma Aldrich, Germany) at $37^{\circ} \mathrm{C}$ in a humidified atmosphere containing $5 \% \mathrm{CO}_{2}$. Passages were performed at appropriate intervals for cytotoxicity studies while the cells continued growing.

\subsubsection{Cytotoxicity assay}

Cytotoxicity of formulations on NIH-3T3 mouse embryonic fibroblast cells were determined by MTT (3-(4,5-dimethyl thiazol-2yl)-2, 5-diphenyl tetrazolium bromide) assay method [45, 46]. Briefly, cells were cultured in 96-well flat-bottom (Greiner CellStar, Germany) culture plates for $24 \mathrm{~h}\left(2 \times 10^{4}\right.$ cells per well). After $24 \mathrm{~h}$ of preincubation, fresh growth media which contained different concentrations of formulations were added to the wells to give final concentrations in the range of 5-1000 $\mu \mathrm{g} \cdot \mathrm{mL}^{-1}$. Cytotoxic effects of formulations were evaluated at the end of 24 and 48 -h incubation. Following removal of culture medium, $20 \mu \mathrm{L}$ MTT solution (5 mg.mL-1 in PBS) was added and the plates were incubated for 4 hours. At the end of the incubation time, formazan crystals were solubilized by adding $200 \mu \mathrm{L}$ DMSO to each well and absorbances were 
determined at $570 \mathrm{~nm}$ with a microplate reader (BioTek Cytation5, Germany). Results were expressed as the percentage of inhibition compared to control cells where cell survival was presumed to be $100 \%$. Cells treated with medium only served as a control group. Control cells were Experiments were performed in triplicate.

\subsection{In vivo study}

Both sex Swiss Albino mice (30-35 g) were used for in vivo studies. During the study, all animal experiments were carried out in accordance with the ethical rules laid down by the International Association of Pain Research (IASP) and the EU Directive 2010/63 / EU for animal experiments. Animal experiments were approved by the ethical committee of Eskişehir Osmangazi University Animal Experiments Local Ethics Committee (Decision No: 519-1, 12.05.2016). Animals were housed at $20 \pm 2^{\circ} \mathrm{C}$ with $12 \mathrm{~h} \mathrm{light/dark}$ cycle and had free access to water and food. Mice were brought to the experimental room 1 day before the study and thus adaptation was provided. They were starved $12 \mathrm{~h}$ before application to prevent possible interactions.

3 groups were formed for hot plate and tail immersion tests (physiological saline control group, pure DT and COMP-DT). Experimental animals were randomly distributed in groups of 8 mice (4 males and 4 females). In the writhing test, the same groups were formed but every test hour had different groups because acetic acid could be administered once to each mice. Animals for writhing test were randomly grouped with 6 mice ( 3 males and 3 females).

COMP-DT (containing $\left.10 \mathrm{mg} \cdot \mathrm{kg}^{-1} \mathrm{DT}\right)$ and DT $\left(10 \mathrm{mg} \cdot \mathrm{kg}^{-1}\right)$ were orally administered in $0.1 \mathrm{~mL}$ physiological saline by a gavage needle. DT was dissolved in saline prior to administration while COMP-DT was administered directly. Control values were determined before drug application in hot plate and tail immersion tests. Data for the $1^{\text {st }}, 3^{\text {rd }}, 6^{\text {th }}$ and $9^{\text {th }} \mathrm{h}$ following drug administration were collected. In the writhing test, separate groups were set up for a separate control group and for each item to be measured.

\subsubsection{Hot plate test}

Pain reflexes in response to thermal stimulus were measured using Hot Plate Analgesia Meter from Ugo Basile Instruments (No. 7280). Mice were put on the hot plate at $55 \pm 0.5^{\circ} \mathrm{C}$ for testing. Reaction times (hind paw licking, hind paw flicking or jumping) of pain responses at the $1^{\text {st }}, 3^{\text {rd }}, 6^{\text {th }}$ and $9^{\text {th }} \mathrm{h}$ after drug administration were measured. The cutoff time was $20 \mathrm{sec}$ for analgesic assays [47].

\subsubsection{Tail immersion test}

Tail immersion method was used to evaluate the central mechanism of analgesic activity. Pain reactions of animals were produced by thermal stimulus though dipping tail tips into hot water. An area of tail was marked and immersed in water bath thermostatically maintained at $52.5 \pm 0.2^{\circ} \mathrm{C}$ (Heto, Allerod, Denmark). Withdrawal time of tail from hot water (in sec) was noted as the reaction time. Test was started $30 \mathrm{~min}$ after application. The maximum cutoff time for immersion was $15 \mathrm{sec}$ to avoid tissue injury [47].

\subsubsection{Writhing test}

This method was selected to evaluate the peripheral antinociceptive effect. Acetic acid induced writhing test is a chemical visceral pain model. Mice were injected with $10 \mathrm{~mL} . \mathrm{kg}^{-1}$ of $0.6 \%$ acetic acid solution (i.p.) 30 min after the administration of DT or formulations. Number of writhes was counted 5 min after administering acetic acid for a duration of $10 \mathrm{~min}$ [47].

\subsubsection{Statistical analysis}

Statistical analyses were performed by two-way ANOVA followed by Bonferroni's multiple comparison tests using GraphPad Prism version 5.0. The results were expressed as the mean \pm SE to show variation between groups. Differences were considered significant when $p \leq 0.05$. Results of the tail immersion and hot plate tests were given as the percentage of maximal possible effect $(\mathrm{MPE} \% \pm \mathrm{SE}$ ) which was calculated with Equation 2 [47].

$$
M P E \%=\left(\frac{\text { Postdrug latency-Predrug latency }}{\text { Cutoff time-Predrug latency }}\right) \times 100
$$


Acknowledgements: This study was financed by Anadolu University Scientific Research Project Foundation (No: 1502S081). The authors would like to thank Abdi İbrahim (İstanbul, Turkey) for providing a gift sample of dexketoprofen trometamol. Faculty of Engineering is acknowledged for XRD, Faculty of Science for SEM, DOPNALAB Anadolu University Faculty of Pharmacy and AUBIBAM for FT-IR and ${ }^{1} \mathrm{H}-\mathrm{NMR}$ analysis facilities.

Author contributions: Concept - AAÖ, EY, YY; Design - AAÖ, EY, YY; Supervision - AAÖ, EY, YY Resource - AAÖ, EY, YY; Materials - AAÖ, EY, YY; Data Collection and/or Processing. AAÖ; Analysis and/or Interpretation - AAÖ; In vivo animal study - AAÖ, RA; Cyctotoxity - AAÖ, BŞ Literature Search - AAÖ; Writing - AAÖ; Critical Reviews AAÖ, EY, RA, BŞ, YY.

Conflict of interest statement: The authors declare no conflict of interest.

Ethics committee approval: Animal experiments were approved by the ethical committee of Eskişehir Osmangazi University Animal Experiments Local Ethics Committee (Decision No: 519-1, 12.05.2016).

\section{REFERENCES}

[1] Sternke EA, Abrahamson K, Bai MJ. Comorbid chronic pain and depression: patient perspectives on empathy. Pain. Manag Nurs. 2016; 17(6): 1-9. [CrossRef]

[2] Öztürk AA, Yenilmez E, Yazan Y. Dexketoprofen trometamol-loaded Eudragit@ RL 100 nanoparticle formulation, characterization and release kinetics. Acta Pharm Sci. 2018; 57(1): 69-84. [CrossRef]

[3] Dugowson CE, Gnanashanmugam P. Nonsteroidal anti-inflammatory drugs. Phys Med Rehabil Clin N Am. 2006; 17: 347-354. [CrossRef]

[4] Öztürk AA, Yenilmez E, Şenel B, Arslan R, Yazan Y. Dexketoprofen trometamol-loaded Kollidon ${ }^{\circledR}$ SR and Eudragit ${ }^{\circledR}$ RS 100 polymeric nanoparticles: formulation and in vitro-in vivo Evaluation. Lat Am J Pharm. 2017;36(11):2153-2165.

[5] Matsui H, Shimokawa O, Kaneko T, Nagano Y, Rai K, Hyodo I. The pathophysiology of nonsteroidal antiinflammatory drug (NSAID) induced mucosal injuries in stomach and small intestine. J Clin Biochem Nutr. 2011; 48(07): 107-111. [CrossRef]

[6] Carabaza A, Cabré F, Rotllan E, Gómez M, Gutiérrez M, García ML, Mauleón D. Stereoselective inhibition of inducible cyclooxygenase by chiral nonsteroidal anti-inflammatory agents. J Clin Pharmacol. 1996; 36: 505-512. [CrossRef]

[7] Burke D, Bannister J. Dexketoprofen trometamol in post-operative pain management. Acut Pain. 2003 ; 5: 57-62. [CrossRef]

[8] Mauleón D, Artigas R, García ML, Carganico G. Preclinical and clinical development of dexketoprofen. Drugs. 1996; 5(24): 24-46. [CrossRef]

[9] Mainardi F, Maggioni F, Pezzola D, Zava D, Zanchin G. Dexketoprofen trometamol in the acute treatment of migraine attack: a phase II, randomized, double-blind, crossover, blank controlled, dose optimization study. J Pain. 2014; 15(4): 388-394. [CrossRef]

[10] Müller RH, Mäder K, Gohla S. Solid lipid nanoparticles (SLN) for controlled drug delivery-a review of the state of the art. Eur J Pharm Biopharm. 2000; 50(1): 161-177. [CrossRef]

[11] Mehnert W, Mäder K. Solid lipid nanoparticles-Production, characterization and applications. Adv Drug Deliv Rev. 2012; 64: 83-101. [CrossRef]

[12] Garud A, Singh D, Garud N. Solid lipid nanoparticles (SLN): method, characterization and applications. Int Curr Pharm J. 2012; 1(11): 384-393. [CrossRef]

[13] Öztürk AA, Gündüz AB, Özışık O. Supervised machine learning algorithms for evaluation of solid lipid nanoparticles and particle size. Comb Chem High Thoughput Screen. 2018; 21(9): 693-699. [CrossRef]

[14] Santos HM, Capelo JL. Trends in ultrasonic-based equipment for analytical sample treatment. Talanta. 2007; 73: 795802. [CrossRef]

[15] Kaur I, Ellis LJ, Romer I, Tantra R, Carriere M, Allard S, Mayne-L'Hermite M, Minelli C, Unger W, Potthoff A, Rades S, Valsami-Jones E. Dispersion of nanomaterials in aqueous media: towards protocol optimization. J Vis Exp. 2017; 130: 56074. [CrossRef]

[16] Aburahma MH, Badr-Eldin SM. Compritol 888 ATO: a multifunctional lipid excipient in drug delivery systems and nanopharmaceuticals. Expert Opin Drug Deliv. 2014; 11(12): 1865-1883. [CrossRef] 
[17] Pandya JB, Parmar RD, Soniwala MM, Chavda JR. Solid lipid nanoparticles: overview on excipients. AJPTI. 2013; 01(03): 1-9.

[18] Franco F, Pérez-Maqueda LA, Pérez-Rodríguez JL. The effect of ultrasound on the particle size and structural disorder of a well-ordered kaolinite. J Colloid Interface Sci. 2004; 274: 107-117. [CrossRef]

[19] Lopedota A, Trapani A, Cutrignelli A, Chiarantini L, Pantucci E, Curci R, Manuali E, Trapani G. The use of Eudragit RS 100/cyclodextrin nanoparticles for the transmucosal administration of glutathione. Eur J Pharm Biopharm. 2009; 72: 509-520. [CrossRef]

[20] Numanoglu U, Tarımc1 N., Characterization of solid lipid nanoparticles (SLNTM) and their pharmaceutical and cosmetic applications. J Fac Pharm Ankara. 2006; 35(3): 211-235.

[21] Nagarwal RC, Kant S, Singh PN, Maiti P, Pandit JK. Polymeric nanoparticulate system: a potential approach for ocular drug delivery. J Control Release. 2009; 136: 2-13. [CrossRef]

[22] Venkateswarlu V, Manjunath K. Preparation, characterization and in vitro release kinetics of clozapine solid lipid nanoparticles. J Control Release. 2004; 95: 627-638. [CrossRef]

[23] Büyükköroğlu G, Yazan Y, Öner AF. Preparation and physicochemical characterizations of solid lipid nanoparticles containing DOTAP for DNA delivery. Turk J Chem. 2015; 39: 1012-1024.

[24] Başaran E, Demirel M, Sırmagül B, Yazan Y. Cyclosporine-A incorporated cationic solid lipid nanoparticles for ocular delivery. J Microencapsul. 2010; 27(1): 37-47. [CrossRef]

[25] Jenning V, Gohla SH. Comparison of wax and glyceride solid lipid nanoparticles (SLN®). Int J Pharm. 2000; 196: 219222. [CrossRef]

[26] Öztürk AA, Martin-Banderas L, Cayero Otero MD, Yenilmez E, Şenel B, Yazan Y. Dexketoprofen trometamol-loaded poly-lactic-co-glycolic acid (PLGA) nanoparticles: preparation, in vitro characterization and cyctotoxity. Trop J Pharm Res. 2019; 18(1): 1-11. [CrossRef]

[27] Jenning V, Mader K, Gohla S. Solid lipid nanoparticles (SLNTM) based on binary mixtures of liquid and solid lipids: A ${ }^{1}$ H-NMR study. Int J Pharm. 2000; 205: 15-21. [CrossRef]

[28] Bucolo C, Drago F, Salomone S. Ocular drug delivery: a clue from nanotechnology. Front Pharmacol. 2012; 130(2): 192-201. [CrossRef]

[29] Zhang Y, Huo M, Zhou J, Zou A, Li W, Yao C, Xie S. DDSolver: an add-in program for modeling and comparison of drug dissolution profiles. AAPS J. 2010; 12: 263-271. [CrossRef]

[30] Dash S, Murthy PN, Nath L, Chowdhury P. Kinetic modeling on drug release from controlled drug delivery systems. Acta Pol Pharma. 2010; 67(3): 217-223.

[31] Zuo J, Gao Y, Bou-Chacra N, Löbenberg R. Evaluation of the DDSolver software applications. BioMed Res Int. 2014; Article ID 204925: 1-9. [CrossRef]

[32] Kırımlığlu GY, Yazan Y, Erol K Ünel ÇÇ. Gamma-aminobutyric acid loaded halloysite nanotubes and in vitro-in vivo evaluation for brain delivery. Int J Pharm. 2015; 495(2): 816-826. [CrossRef]

[33] Baek JS, Cho CW. Comparison of solid lipid nanoparticles for encapsulating paclitaxel or docetaxel. J Pharm Invest. 2015; 45: 625-631. [CrossRef]

[34] Wang JY, Wang Y, Meng X. Chitosan nanolayered cisplatin-loaded lipid nanoparticles for enhanced anticancer efficacy in cervical cancer. Nanoscale Res Lett. 2016; 11: 524-535 [CrossRef]

[35] Olbrich C, Bakowsky J, Leh CM, Müller RH, Kneue C., Cationic solid-lipid nanoparticles can efficiently bind and transfect plasmid DNA. J Control Release. 2001; 77: 345-355. [CrossRef]

[36] Yuan H, Miao J, Du YZ, You J, Hu FQ, Zeng SU. Cellular uptake of solid lipid nanoparticles and cytotoxicity of encapsulated paclitaxel in A549 cancer cells. Int J Pharm. 2008; 348: 137-145 [CrossRef]

[37] Sagir O, Sunay FB, Yildirim H, Aksoz E, Ozaslan S, Koroglu A, Aydemir T, Ulusa AE, Kockar F. Evaluation of the effects of dexketoprofen trometamol on knee joint: an in vivo \& in vitro study. Indian J Med Res. 2013; 138(6): 912918.

[38] Shah KA, Date AA, Joshi MD, Patravale VD. Solid lipid nanoparticles (SLN) of tretinoin: potential in topical delivery. Int J Pharm. 2007; 345: 163-171. [CrossRef]

[39] Siddiqui A, Alayoubi A, El-Malah Y, Nazzal S. Modeling the effect of sonication parameters on size and dispersion temperature of solid lipid nanoparticles (SLNs) by response surface methodology (RSM). Pharm Dev Technol. 2014; 19(3): 342-346. [CrossRef] 
[40] Archana K, Vikas P. Development and validation of reversed-phase high performance liquid chomatographic method for estimation of dexketoprofen trometamol in bulk and tablet dosage form. AJPCT. 2013; 4: 395-400.

[41] Öztürk AA, Yenilmez E, Yazan Y. Development and validation of high performance liquid chomatography (HPLC) modified method for dexketoprofen trometamol. EIJST. 2017; 6(4): 33-41.

[42] Ash M, Ash I. Handbook of Green Chemicals. Second.Ed. Synapse Info Resources, New York, 2004.

[43] MedicinesComplete, Glyceryl Behenate, https://www.medicinescomplete.com/mc/excipients/2012/1001938956.htm, 2017

[44] Khoshneviszadeh R, Bazzaz BSF, Housaindokht MR, Ebrahim-Habibi A, Rajabi O. A comparison of explanation methods of encapsulation efficacy of hydroquinone in a liposomal system. J Paramed Sci. 2016; 7(2): 23- 28.

[45] Mosmann T. Rapid colorimetric assay for cellular growth and survival: application to proliferation and cytotoxicity tests. J Immunol Methods. 1983; 65: 55-63. [CrossRef]

[46] Gencer S, Cebeci A, Irmak-Yazicioglu MB. Silencing of the MMP-3 Gene by siRNA Transfection in Gastric Cancer AGS Cells. J Gastrointestin Liver Dis. 2010; 20: 19-26.

[47] Arslan R, Bektas N, Ozturk Y. Antinociceptive activity of methanol extract of fruits of Capparis ovata in mice. J. Ethnopharmacol. 2010; 131: 28-32. [CrossRef]

This is an open access article which is publicly available on our journal's website under Institutional Repository at http://dspace.marmara.edu.tr. 